Научная статья

УДК $502.7(-965.16)$

DOI $10.18101 / 2587-7143-2021-3-64-72$

\title{
ПРИРОДНОЕ И КУЛЬТОВОЕ НАСЛЕДИЕ ОЗЕРА БАЙКАЛ И СОПРЕДЕЛЬНЫХ ТЕРРИТОРИЙ *
}

\author{
(c) Иметхенов Анатолий Борисович \\ доктор географических наук, профессор \\ Восточно-Сибирский государственный университет технологий и управления, \\ Россия, 670013, г. Улан-Удэ, ул. Ключевская, 40В
}

\begin{abstract}
Аннотация. В статье обобщены материалы, собранные автором во время многочисленных экспедиций по Байкалу и побережьям. Автор на примере озера Байкал и прилегающих природных территорий Саян, Прибайкалья и Забайкалья подробно раскрывает наиболее почитаемые культовые места, которые стали объектами паломничества и массового посещения.
\end{abstract}

Ключевые слова: ландшафтные достопримечательности, священные и культовые места, памятники природы.

\section{Для цитирования}

Иметхенов А. Б. Природное и культовое наследие озера Байкал и сопредельных территорий // Вестник Бурятского государственного университета. Биология, география. 2021. № 3. С. 64-72.

Введение. Весьма почитаемые природные объекты были известны еще в глубокой древности и связаны прежде всего с религиозно-мифологическими воззрениями разной эпохи. Они сыграли главенствующую роль в становлении сакрально-политических центров объединения родовых, племенных и общенародных этнических групп. При этом существующая реальность вносит свои коррективы в обычаи и традиции народов и хорошо вписывается в реальную жизнь той или иной религии.

В последние годы многие исследователи обсуждают проблемы, связанные с преемственностью материальной, духовной и этнической культуры народов, живущих вокруг оз. Байкал $[1 ; 5]$. В этих научных публикациях впервые было уделено внимание памятникам природы культового значения, которые имеют существенное значение в познании своих национальных исторических святынь.

Неслучайно на местах сосредоточения природных объектов культового характера особый интерес представляют уникальные мысы и бухты, причудливые скалы и прибрежные панорамы, красивейшие водопады и лабиринты таинственных пещер, множество минеральных источников и озер. Они стали символами Байкала, его ключевыми образами, имеющими величайшую эстетическую ценность. В этой связи особый интерес представляют образы Байкала и его горные обрамления, их священные и неприкосновенные памятники, вокруг которых консолиди-

\footnotetext{
* Статья переиздана и посвящена памяти А. Б. Иметхенова: Природное и культовое значение озера Байкал // Роль особо охраняемых природных территорий в сохранении биоразнообразия: материалы IV Международной научно-практической конференции. Чебоксары, 2015. С. 164-170.
} 
А. Б. Иметхенов. Природное и культовое наследие озера Байкал и сопредельных территорий

ровалась таежная культура народов Прибайкалья. Одновременно вокруг горной системы Хангая в Центральной Азии формировалось ядро культуры степных кочевников Северной Монголии [2; 3].

История изучения вопроса. В условиях таежного единства народов Прибайкалья и Северной Монголии, объединенных притягательной силой Байкала и Хингая, в разных ландшафтных условиях сформировался уникальный культ «Земля - Вода». Оба объекта имеют наиболее значимые культовые святилища, где, якобы, обитали духи и божества общенародного значения. Например, уже с начала эпохи бронзы на Хингае размещались центры всех центральноазиатских племенных объединений и государственных формирований. А природный и культовый феномен Байкала и его горное обрамление до сих пор не познаны, хотя достоверно известно глубокое почитание этого наиважнейшего географического объекта в глубокой древности. Об этом свидетельствует наличие множества культовых мест родоплеменного значения Прибайкалья, Забайкалья и Восточного Саяна, игравших значительную роль по отношению к образу Байкала. Безусловно, эти территории, центром которых явился Байкал, способствовали не только почитанию культовых мест, но и консолидации более мелких этнических групп вокруг этой уникальной культовой территории. В дальнейшем все больше стали почитаться пантеон духов и формы обрядности традиционного шаманизма. Примером могут служить уникальные природные объекты Восточного Саяна, связанные с легендарными деяниями Абай Гэсэра, - отдельные горы, лавовые потоки, вулканические аппараты и т. д. [6].

В дальнейшем реальные события привели к тому, что люди начали почитать и обожествлять природные объекты за их необычность и уникальность. Это, прежде всего, причудливые формы рельефа, особо ценные виды животных и растений, своеобразные геологические обнажения и разрезы, имеющие исключительно важную роль как объекты культового характера. Всеми этими уникальными и причудливыми свойствами обладают оз. Байкал и его горное обрамление [5].

Материалы исследований. В статье обобщены материалы, собранные автором во время многочисленных экспедиций по Байкалу и его побережьям. Однако в огромном потоке публицистических материалов по Байкалу практически не просматривается еще одна замечательная, но малоизученная широкому кругу специалистов и любителей природы грань Байкала - его сакральное и духовное наследие, представляющее собой ландшафтные достопримечательности культового значения. Наиболее часто встречаемые природные священные места Байкала и его горного окружения нами представлены в таблице 1.

Типизация священных и сакральных мест оз. Байкал

Таблица 1

\begin{tabular}{|l|l|l|}
\hline Типизация священных мест & Название священных мест & \multicolumn{1}{|c|}{ Место расположения } \\
\hline Священные культовые горы & $\begin{array}{l}\text { «Ехе-Ерд» - священная } \\
\text { культовая гора; } \\
\text { Скала Бурхан - священное } \\
\text { культовое место }\end{array}$ & $\begin{array}{l}\text { Западное побережье (Байкала, } \\
\text { устье р. Анга) } \\
\text { Остров Ольхон (мыс Шаманка) }\end{array}$ \\
\hline $\begin{array}{l}\text { Чудесное появление } \\
\text { «предметов» на скалах }\end{array}$ & $\begin{array}{l}\text { Священная «янжима»- } \\
\text { сакральный памятник Во- } \\
\text { сточной Сибири }\end{array}$ & $\begin{array}{l}\text { Баргузинская долина (местность } \\
\text { Униган у подножья Баргузинского } \\
\text { хребта) }\end{array}$ \\
\hline
\end{tabular}




\begin{tabular}{|c|c|c|}
\hline $\begin{array}{l}\text { Камни как места поклоне- } \\
\text { ния }\end{array}$ & $\begin{array}{l}\text { «Бухэ-шулун» (Бык-камень) } \\
\text { - сакральный памятник } \\
\text { природы; } \\
\text { Загадочный знак «Пять } \\
\text { пальцев» }\end{array}$ & $\begin{array}{l}\text { Баргузинская долина (подножье } \\
\text { Икатского хребта) } \\
\text { Тугнуйская долина (местность } \\
\text { Тугнуйские столбы) }\end{array}$ \\
\hline $\begin{array}{l}\text { Пещеры - лабиринты под- } \\
\text { земного царства }\end{array}$ & Байденские пещеры & Западное побережье оз. Байкал \\
\hline $\begin{array}{l}\text { Камни-валуны - следы } \\
\text { былых катастроф }\end{array}$ & $\begin{array}{l}\text { Жомболокский «сад кам- } \\
\text { ней»; } \\
\text { Инский «сад камней» }\end{array}$ & $\begin{array}{l}\text { Окинское плоскогорье (долина } \\
\text { р. Жомболок) } \\
\text { Баргузинская долина (устье } \\
\text { р. Ина притока р. Баргузин). }\end{array}$ \\
\hline $\begin{array}{l}\text { Загадочные знаки - память } \\
\text { о прошлом }\end{array}$ & $\begin{array}{l}\text { Знаки-пиктографы на от- } \\
\text { весной скале Монголжон }\end{array}$ & $\begin{array}{l}\text { Окинское плоскогорье (долина } \\
\text { р. Жомболок) }\end{array}$ \\
\hline $\begin{array}{l}\text { Священные места, отме- } \\
\text { ченные рисунками }\end{array}$ & $\begin{array}{l}\text { Утес Саган-Заба, бухта Ая - } \\
\text { наскальные рисунки древ- } \\
\text { них людей }\end{array}$ & $\begin{array}{l}\text { Западный берег Байкала (мест- } \\
\text { ность Халы, бухта Ая) }\end{array}$ \\
\hline $\begin{array}{l}\text { Природно-рукотворные } \\
\text { творения человека }\end{array}$ & $\begin{array}{l}\text { Ботогольский графитовый } \\
\text { рудник Алибера }\end{array}$ & $\begin{array}{l}\text { Восточный Саян (Ботогольский } \\
\text { голец) }\end{array}$ \\
\hline $\begin{array}{l}\text { Чудеса исцеления. О мине- } \\
\text { ральных источниках }\end{array}$ & $\begin{array}{l}\text { Минеральные источники в } \\
\text { местности Шумак и Жойган }\end{array}$ & $\begin{array}{l}\text { Восточный Саян (долины рек } \\
\text { Шумак и Арак-Хем) }\end{array}$ \\
\hline $\begin{array}{l}\text { Почитаемые деревья- } \\
\text { долгожители }\end{array}$ & $\begin{array}{l}\text { Лиственница-долгожитель } \\
\text { (Тункинская долина) }\end{array}$ & $\begin{array}{l}\text { Подножье Тункинских гольцов } \\
\text { (р. Кынгырга, курорт Аршан) }\end{array}$ \\
\hline
\end{tabular}

\section{Священные культовые горы}

Мыс Скала-Шаманка. Самым почитаемым и священным местом на Байкале считается пещера в мысе Скала-Шаманка («Бурхан») на о. Ольхон. Расположенный на вершине мыса Шаманка некрополь представляет собой сложное культовое место, где вперемежку с надмогильными кладками размещались жертвенники различных типов, а жертвенные приношения располагались по всей территории кладбища. Здесь с древних времен совершались грандиозные обрядовые действия с жертвоприношениями. Академик В. А. Обручев (1890) писал по этому поводу: «...но всего замечательнее суеверный страх, который ольхонские буряты питают к пещере». В частности, он указывал, «мимо Шаманской скалы нельзя проезжать на колесах, а только верхом или на санях, почему в летнее время сообщение между западной и восточной частями Ольхона производится только верхом, да и то в редких случаях, так как буряты вообще неохотно ездят мимо пещеры...» [9].

Ритуалы, связанные с культом эжина (хозяина) Ольхона, свидетельствуют о существовании у байкальских племен особо почитаемых священных и культовых мест на Байкале. Следы былых жертвоприношений домашними животными со своеобразными ритуалами видели многие путешественники и естествоиспытатели прошлых эпох Ж. Б. Жербильон, И. Идес, А. Брант, русские академические ученые немецкого происхождения Д. Г. Мессершмидт, И. Г. Гмелин, П. С. Паллас и И. Г. Георги, ученые, польские ссыльные А. Л. Чекановский. И. Д. Черский, Б. И. Дыбовский, российские ученые-естествоиспытатели П. А. Кропоткин, Г. И. Радде и известные ученые-академики В. А. Обручев, В. Н. Сукачев, А. П. Окладников и другие. 

торий

В настоящее время скала Шаманка как природный феномен стала центром мирового шаманизма, объектом всеобщего обозрения и самым посещаемым местом на Байкале.

Священная гора Ехе-Ерд. Среди прибайкальских бурят бытует предание о грандиозных межплеменных играх, которые в старину проводились ежегодно в устье р. Анга (Приольхонье). Игры организовывались вокруг небольшой горки Ехе-Ерд, представляющей собой большой холм идеальной конусовидной формы. Здесь в старину из года в год проводились массовые пляски нескольких тысяч человек. Люди съезжались сюда со всех концов Восточной Сибири и Центральной Азии. Одновременно тысячи танцоров устраивали танцы («ехор») вокруг горы на протяжении шести суток - и днем и ночью. Для того чтобы игрище состоялось, предъявлялось одно единственное условие - участников должно собраться не менее тысячи человек, чтобы они, взявшись за руки, могли опоясать горку, замкнув хороводный круг. Паломничество несколько тысячи человек, преодолевавших сотни и даже тысячи километров по степям и болотам, горам и таежным чащам, являлось событием всемонгольского масштаба. Значимость сакрального памятника Ехе-Ерд подтверждается тем, что в 2000, 2005 и 2010 гг. здесь проводились грандиозные игрища после 500-летнего перерыва. Сюда к священной горе съехались гости со всей этнической Бурятии, Республики Тыва, Республики Саха-Якутия, соседней Монголии и Китая, всего на играх участвовало более 10 тыс. человек. Таким образом, священная гора Ехе-Ерд стала самым значимым культовым местом народов, живущих не только вокруг Байкала, но и жителей Северной и Центральной Азии [3].

Священная гора Ехе-Ерд явилась крупнейшим центром курыканской (древне бурятской) земли. Здесь кроме массовых игрищ проводились грандиозные обряды в честь божеств Земли-Воды (Йер-Су) и верховного бога-творца Байкала Айа. Для проведения такого грандиозного общенародного праздника требовалось наличие оригинальной конусовидной горы правильной формы и большой воды. Всем этим требованиям отвечала гора Ерд и непосредственная близость оз. Байкал, именуемая бурятами священным морем - Далай.

\section{Чудесное появление «предметов» на священных местах}

Кроме священных культовых гор отмечено чудесное появление «предметов» на скалах или на крупных валунах. Наиболее значимым и представительным сакральным памятником Бурятии считается священная «Янжима». Такие сакральные места, представляющие собой «рукотворные предметы» и расположенные на священных местах, как правило, обрастают легендами. Образ богини Янжимы уникальное явление в буддийском мире, проявилось недавно на большом валуне в местности Униган у подножия Баргузинского хребта. Теперь к Янжиме устремляются тысячи паломников, особенно молодые супружеские пары, прося у богини рождения детей. Феномен Янжимы можно связывать с внедрением ламаистской веры на берегах Байкала. И когда ламы узнали о предстоящих репрессиях властей, провели на этой местности ритуальные действия, считая, что их учения со временем станут достоянием их потомков.

\section{Камни как места поклонения}

Многие камни считаются своеобразными культовыми памятниками и состоят из «жертвенных комплексов» и, как правило, занимают небольшие площади в 
низинах широких падей по берегам Байкала и в долинах крупных рек, составляют часть привлекательного ландшафта и постоянно являются местом паломничества верующих, которые устаивают жертвенные ритуалы. Таким весьма выразительным и необычным камнем считается Бухэ-шулун, расположенный у подножия Икатского хребта (Баргузинская долина), и Пять пальцев в Тугнуйской долине. Местные жители издавна эти «жертвенные комплексы» считают весьма почитаемым местом, совершают родовые, общеродовые и племенные шаманские обряды. Такие комплексы могут состоять из отдельного крупного валуна или же из групп камней, где в центре обязательно должен возвышаться камень особо крупного размера. К сожалению, сведений о пантеоне местных духов в характере ритуальных действий до сих пор не обнаруживается. Однако многие исследователи считают, что, скорее всего, такие действия связаны со старинными преданиями о происхождении шаманов или же с проявлением катастрофических природных процессов и явлений, которые оказывали на коренное население панический страх и устрашающие действия.

\section{Камни-валуны - следы былых катастроф}

О камне, сотворенном рукой человека, написано много, а о естественном саде камней, созданном самой природой, мало сведений. Они также весьма почитаемы коренным населением, хотя не связаны с ритуальными обрядами. Такими удивительными феноменами считаются Жомболокский и Инский сады камней.

Инский сад камней, открытый автором в 1978 г., расположен в юго-западной части Баргузинской долины на участке выхода р. Ина из Икатского хребта и за-

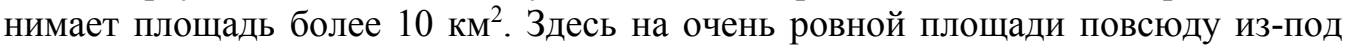
земли возвышаются крупные глыбы гранита размером до 10-15 м в поперечнике, напоминающие архипелаг островов в океане или пейзаж, редко доступный современному земному наблюдателю. Камни-глыбы не только внушительны по размерам, но и своеобразны по залеганию. По нашему мнению, инские глыбы образовались в результате недавнего гигантского выброса крупноглыбового материала (около 10-15 тыс. лет), имевшего катастрофический характер [2].

Большую известность получил также Жомболокский сад камней, открытый мною 2006 г. Он расположен в Восточном Саяне в местности Хухэ-Байса (Синяя скала) долины р. Жомболок на высоте 1562 м над уровнем моря. В настоящее время от следов былых катастроф ничего практически не осталось. Привлекают здесь не только камни-глыбы, но и богатая растительность, напоминающая черневую тайгу. Образование Жомболокского сада камней связано с сейсмическим воздействием, сопровождающимся подземными толчками, в результате которого произошли крупные обвалы горных пород, а также громадные сейсмогравитационные оползни.

Сады камней природного характера не только внушительны по размерам, но и своеобразны по залеганию. Следовательно, они имеют не только научный интерес, но и представляют большую познавательную и эстетическую ценность. Такие уникальные природные феномены также нуждаются в охране.

\section{Загадочные знаки - память о прошлом}

Отдельные отвесные скалы с загадочными знаками как природные объекты (урочища, останцовые горы, речные и озерные террасы, мысы, пещеры и отдельные скалы-утесы) также несут следы материальной и духовной культуры про- 

торий

шлых эпох и являются свидетелями многих исторических событий. Эти странные знаки-пиктографы впервые обнаружил в 1858 г. известный исследователь Сибири П. А. Кропоткин [7].

Загадочные пиктографы, не встречающиеся в других местах Сибири, нарисованы на карнизе скалы (в песчаниках) на высоте 20 м в пределах 25 м друг от друга на крутом утесе Монголжон. Знаки представляют собой изображения типа ракетки. Верхний конец каждой из пяти «ракеток» пересекает поперечная поло$\mathrm{ca}$, ниже от которой помещается точка. Рисунки нанесены красной охрой и исчерчены короткими вертикальными линиями.

Многие исследователи Восточного Саяна по-разному трактуют их происхождение. Но наиболее достоверными считаются те выводы современных исследователей, которые появление таинственного знака приурочивают к более позднему памятнику древней истории края. С этим периодом связано появление буддийских «мани...» и первое проникновение новой религии (буддизма) в среду шаманистов. Но наиболее достоверными считается мнение профессора Г. Ц. Цыбикова, который в этих пиктографах увидел изображения родового оберегающего знака - Цзендемуни-тамга, заимствованного из буддизма, что дословно означает «волшебная драгоценность» или «три сокровища» [4].

\section{Священные места, отмеченные рисунками}

Во многих местах побережья Байкала встречаются весьма почитаемые и обрядовые места, «помеченные» удивительными наскальными изображениями. Они известны с давних времен своим большим количеством рисунков, выполненных рельефной техникой путем пробивания темной поверхности скальной породы из мрамора. Древние изображения датированы концом неолита и бронзой. Из наиболее известных рисунков, изображающих охоту и быт древних людей, можно выделить Саган-Заба и Ая, которые вот уже около 5 тыс. лет привлекают к себе людей. Они расположены на западном побережье Байкала в бухте Саган-Заба (Крестовый мыс) и бухте Ая. Работавший в конце 60-х годов прошлого столетия академик А. П. Окладников (1950) обнаружил множество изображений (силуэтов) шаманов с поднятыми руками, означающих молитвенные обращения к небу, и воинов с боевыми секирами в руках. Некоторые композиции изображают сцены молитвы над убитыми или умершими сородичами. Он писал, что «петроглифы в бухте Саган-Заба с их грандиозной некогда, но и до сих пор поражающей своими масштабами многофигурной композицией антропоморфных изображений представляют собой уникальное явление среди всех других наскальных изображений Сибири... Петроглифы Саган-Заба - подлинная жемчужина древней культуры и искусства народов Сибири. Второго такого памятника этой эпохи нет на всем ее пространстве от Урала до Тихого океана» [9]. Утес Саган-Заба стал одним из уникальнейших природных объектов Байкала, заслуживающим особой охраны с заповедным режимом.

\section{Природно-рукотворные творения человека}

Ярким примером природно-рукотворного творения человека считается технически оснащенный графитовый рудник Алибера (расположен на Ботогольском гольце на высоте 2321 м), представляющий знаменитый памятник горнорудного производства XIX в. Ботогольское месторождение графита имеет более чем 160 -летнюю увлекательную историю, где наиболее яркие его страницы связаны с 
именем французского предпринимателя Жан-Пьера Алибера, величавшего себя «тавазгустским первостатейным купцом». Французский предприниматель Ж.-П. Алибер начал добывать графит только самого высокого качества с 1847 г., но остальную руду и вскрышную породу складывал в правильные каменные стены, напоминающие стены миниатюрной крепости или древнего замка. Графит тщательно отсортировался, распиливался на правильные параллелепипеды и в прочной упаковке отправлялся на лошадях за 7 тыс. км в г. Штейц вблизи Нюрнберга в Баварию на карандашную фабрику А. В. Фабера. В дальнейшем фаберовские карандаши с надписью «Сибирский графит Алибера» получили всеобщее признание как лучшие в мире [6].

Предприимчивый француз добывал не только графит самого высокого качества, а также россыпное золото и нефрит. Одновременно он построил винтовую дорогу с беседками, крестами, стоянками протяженностью 6 км от поселка до самой вершины гольца. На самой вершине Ботогольского гольца на высоте 2321 м обосновал резиденцию с широкой каменной стеной высотой до 6 м и построил два 10-метровых ветрореза. Здесь же он расположил виллу, часовню и построил ипподром и небольшую оранжерею. Все это свидетельствует о высокой культуре французского промышленника, который в одном из глухих угольков Сибири создал первый, технически оснащенный рудник с богатой резиденцией. Кроме того, он построил прекрасный поселок и организовал ферму для яков и коров в долине горной речки Ботогол. Его культурная деятельность не ограничилась этой акцией. Он, развив крупное скотоводство среди сойотов, подарил им свой крупный рогатый скот [6].

Благородное творение Ж.-П. Алибера на Ботогольском гольце видно и через 170 лет. Технически оснащенный рудник Алибера XIX в. может стать уникальным природным и культурным объектом регионального значения и первым природным объектом в системе экологического просвещения, образования и познавательного туризма.

\section{Чудеса исцеления. О минеральных источниках}

На территории Бурятии известны более 300 минеральных источников, а на побережье Байкала около 50. Среди них есть холодные и термальные углекислые, азотно-углекислые, углекисло-азотные, азотные и метановые термы, холодные негазирующие сульфидные, железистые и радоновые воды, которые пользуются огромной популярностью у местного населения. Люди уважительно относятся к ним, считая их священными местами. Наиболее исцеляющими свойствами обладают минеральные источники Шумак и Жойган. Их называют жемчужинами Саян. Чтобы испить целебные воды этих источников и принять чудодейственные ванны, туристы и отдыхающие совершают многокилометровый путь, преодолевая исключительно труднодоступные перевалы и сложные речные преграды. Так, например, в долине р. Шумак, у правого притока р. Китой, среди серебристых елей из недр земли поднимаются углекислые воды, образуя на поверхности многочисленные источники с разнообразными лечебными свойствами. Такое благоприятное сочетание многих ценных свойств минеральных вод Шумака на территории Восточной Сибири встречается впервые [10].

В настоящее время назрела необходимость проведения научных исследований минеральных источников для их рационального использования. Большое значе- 

торий

ние будут иметь бальнеологическая характеристика источников, оценка лечебных факторов и выявление показаний для лечения различных болезней, что представляет уникальную возможность для полноценного отдыха.

\section{Почитаемые деревья-долгожители}

К весьма почитаемым объектам относятся и деревья-долгожители. Так, например, у жителей Тункинской долины наиболее почитаемым деревом считается лиственница-долгожитель, возраст которого насчитывает около 600 лет. Он растет на территории курорта Аршан, имеет высоту более 30 при диаметре около 1,5 м. Могучее дерево, как исполин, возвышается над всей округой. Была бы она еще выше, если бы сильный ветер не обломил вершину. Но даже в свои 600 лет дерево сравнительно не старо - ведь известно, что отдельные экземпляры лиственниц живут до 700-800 лет. Дерево-патриарх, пожалуй, самый древний и единственный свидетель давно минувших веков.

Есть на южном побережье Байкала в устьях рек Снежная, Выдринная, Аносовка и других отдельные деревья тополя пушистого, достигающие высоты до 30 и более метров с диаметром ствола до 2 м [2].

Заключение. Бесценные феномены природы являются не только выдающими памятниками природы и истории, но и вехами культурного и духовного развития человека. Они выступают как носители памяти о прошлом и ориентирами в духовной жизни. Природные и природно-рукотворные святыни являются не только историческими или архитектурно значимыми ансамблями, но своеобразными энергетическими, духовными центрами земли, сила воздействия которых на людей имеет природное начало. Одновременно значимость священных мест заключается в том, что они притягивают народы к определенной территории, а отдельных людей - к своей малой родине, что является своеобразным мотивом к изучению священных и волшебных мест.

\section{Литература}

1. Иметхенов А. Б. Природа переходной зоны на примере Байкальского региона. Новосибирск: Изд-во СО РАН, 1996. 231 с. Текст: непосредственный.

2. Иметхенов А. Б. Памятники природы Байкала. Новосибирск: Наука, 1990. 157 с. Текст: непосредственный.

3. Иметхенов А. Б. Памятники природы Байкала. Улан-Удэ: Буряад унэн, 2002. 168 с. Текст: непосредственный.

4. Иметхенов А. Б. Природные достопримечательности Восточного Саяна. Улан-Удэ: Изд-во ВСГУТУ, 2015. 162 с. Текст: непосредственный.

5. Иметхенов А. Б., Долхонова Э. З., Елбаскин П. Н. Ольхон - край родной. УланУдэ: Изд-во Бурят. гос. ун-та, 1997. 352 с. Текст: непосредственный.

6. Иметхенов А. Б., Шарастепанов Б. Д., Иметхенов О. А. Горная Ока. География Восточного Саяна. Улан-Удэ: Изд-во Бурят. гос. ун-та, 2008. 192 с. Текст: непосредственный.

7. Кропоткин П. А. Поездка в Окинский караул // Зап.-Сиб. отд. РГО. 1867. Кн. IX-X. С. 1-95. Текст: непосредственный.

8. Обручев В. А. Геологические исследования в Иркутской губернии в 1889 г. Изв. ВСОРГО, Иркутск, 1980. Т. 21, № 3. С. 28-29. Текст: непосредственный.

9. Окладников А. П. Неолит и бронзовый век Прибайкалья. Москва; Ленинград: Наука, 1950. Ч. І. С. 84. Текст: непосредственный. 
10. Природный парк «Шумак» / А. Б. Иметхенов, Г. Г. Елаева, Э. Н. Елаев [и др.]. Улан-Удэ: Изд-во Бурят. гос. ун-та, 2012. 120 с. Текст: непосредственный.

Статья поступила в редакцию 02.09.2021; одобрена после рецензирования 06.09.2021; принята к публикации 01.10.2021.

\section{NATURAL AND CULTIC HERITAGE OF LAKE BAIKAL AND ADJACENT TERRITORIES}

Anatoly B. Imetkhenov

Dr. Sci. (Geogr.), Prof.,

East-Siberian State University of Technology and Management

40v Klyuchevskaya St., Ulan-Ude 670013, Russia

Abstract. The article summarizes the materials collected by the author during numerous expeditions around Lake Baikal and the coasts. Using the example of Lake Baikal and the adjacent natural areas - the Sayans, Cisbaikalia and Transbaikalia, he revealed in detail the most revered places of worship that have become objects of pilgrimage and mass visits.

Keywords: landscape attractions, sacred and cult places, natural monuments.

\section{For citation}

Imetkhenov A. B. Natural and Cultic Heritage of Lake Baikal and Adjacent Territories. Bulletin of Buryat State University. Biology, Geography. 2021; 3: 64-72 (In Russ.).

The article was submitted 02.09.2021; approved after reviewing 06.09.2021; accepted for publication 01.10.2021. 